\title{
Islet cell autoimmunity and mitochondrial DNA mutation in Korean subjects with typical and atypical Type I diabetes
}

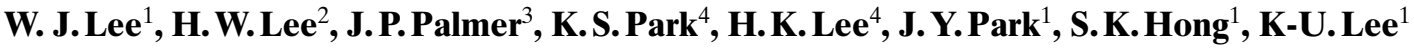 \\ ${ }^{1}$ Division of Endocrinology and Metabolism, Department of Internal Medicine, University of Ulsan College of Medicine, Asan \\ Medical Center, Songpa-ku, Seoul, Korea \\ ${ }^{2}$ Department of Internal Medicine, College of Medicine, Yeungnam University, Taegu, Korea \\ ${ }^{3}$ Department of Internal Medicine, University of Washington, Seattle, Washington, USA \\ ${ }^{4}$ Department of Internal Medicine, Seoul National University College of Medicine, Seoul, Korea
}

\begin{abstract}
Aims/hypothesis. The 1997 American Diabetes Association classification of diabetes mellitus included a subset of Type I diabetic patients who do not need insulin for several years but eventually progress to complete insulin deficiency i.e. atypical Type I diabetes mellitus. In Caucasian populations, most Type I diabetic patients have auto-antibodies against islet cells. We examined the frequency of the auto-antibodies against islet cells and mitochondrial DNA 3243 mutation in Koreans with typical and atypical Type I diabetes mellitus.

Methods. We measured plasma C-peptide level in 1870 consecutive Korean diabetic patients. Of these, 56 patients had insulin deficiency (fasting and glucagon-stimulated plasma C-peptide concentrations 0.2 $\mathrm{nmol} / \mathrm{l}$ and $\leq 0.32 \mathrm{nmol} / \mathrm{l}$, respectively), and they were subdivided into typical $(n=26)$ and atypical Type I (insulin-dependent) diabetes mellitus $(n=30)$ according to clinical manifestation. Islet cell antibody was measured by indirect immunofluorescence. Anti-
\end{abstract}

GAD antibody and anti-ICA512 antibody were measured by radioimmunoassay. Mitochondrial DNA 3243 mutation was detected using restriction enzyme Apa-I digestion of the amplified genomic DNA.

Results. The overall prevalence of auto-antibodies in the typical and atypical groups was $77 \%$ and $57 \%$, respectively. Mitochondrial DNA 3243 mutation was found in 3 out of $30(10 \%)$ of atypical Type I (insulin-dependent) diabetic patients but not in typical Type I (insulin-dependent) diabetic patients.

Conclusion/interpretation. Autoimmunity might not be the only cause of progressive insulin deficiency in Koreans. Mitochondrial DNA mutation is another identifiable cause but the cause(s) of insulin deficiency in the remainder of Type I diabetic patients without autoimmunity is not clear. [Diabetologia (2001) 44: 2187-2191]

Keywords Type I diabetes mellitus, islet cell antibody, anti-GAD antibody, anti-ICA512 antibody, mitochondrial DNA mutation.
Received: 5 June 2001 and in revised form: 27 July 2001

Corresponding author: Dr. K-U. Lee, Division of Endocrinology and Metabolism, Department of Internal Medicine, University of Ulsan College of Medicine, Asan Medical Center, 388-1 Poongnap-dong, Songpa-ku, Seoul, Korea,

e-mail: kulee@www.amc.seoul.kr

Abbreviations: ADA, American Diabetes Association; DKA, diabetic ketoacidosis; GAD, glutamic acid decarboxylase; ICA, islet cell antibody; ICA512, islet cell antigen 512; LADA, latent autoimmune diabetes in adults; MtDNA, mitochondrial DNA; SPIDDM, slowly progressive insulin-dependent diabetes mellitus; WHO, World Health Organization
The 1985 WHO classification of diabetes mellitus considers clinical manifestation and causes [1]. Although insulin-dependent diabetes mellitus (IDDM), non-insulin-dependent diabetes mellitus (NIDDM) and Type I, Type II diabetes, respectively, were considered to be synonymous, IDDM/NIDDM was based on clinical manifestation and Type I/Type II diabetes was based on causation. During the past decade, growing evidence suggested that there is a subset of atypical diabetic patients who initially manifest as NIDDM and do not need insulin for years, but eventually progress to IDDM [2-4]. More importantly, it was found that the presence of auto-antibodies 
to islet cells in NIDDM patients predicts development of absolute insulin deficiency and insulin requirement in the future [4].

The new 1997 American Diabetes Association (ADA) classification [5], taking this into consideration, stated that the clinical spectrum of Type I diabetes mellitus ranges from complete insulin deficiency to mild diabetes not requiring insulin. In Caucasian populations, autoimmune destruction of pancreas beta cells is the most common cause of Type I (insulin-dependent) diabetes, and most of these patients have plasma auto-antibodies against islet cells as a marker of beta cell immune destruction [5-7]. However, it is not clear whether this classification is easily applicable in other populations. Some Type I (insulin-dependent) diabetic patients have permanent insulinopenia but have no evidence of autoimmunity [5]. The prevalence of this kind of Type I (insulin-dependent) diabetes mellitus is known to be higher in populations of African or Asian origin [5]. In fact, we previously found that only $18 \%$ of Korean atypical Type I (insulin-dependent) diabetic patients, who had a period of diabetes not requiring insulin for at least 1 year, were positive for islet cell antibody (ICA) [3]. These findings led us to doubt whether the cause of diabetes in these patients is the autoimmune destruction of pancreatic beta cells.

If autoimmunity is not the only cause of atypical Type I (insulin-dependent) diabetes what would be other causes? One possibility would be a mutation of mitochondrial DNA (mtDNA) at nucleotide pair 3243. This entity was first suggested in 1989 in a pedigree with maternally transmitted diabetes and sensorineural hearing loss [8]. Consequent studies showed that it presented either as IDDM or NIDDM but had a tendency to progress to insulin deficiency [9-16]. As these clinical characteristics are similar to the clinical manifestations of so called slowly progressive IDDM (SPIDDM) [2] or latent autoimmune diabetes in adults (LADA) [4], we assumed that mtDNA mutation could be one of the causes of atypical Type I (insulin-dependent) diabetes in Korean subjects.

This study investigated whether the new ADA classification is easily applicable to Korean diabetic subjects. To this end, we measured three auto-antibodies against islet antigens (ICA, anti-GAD antibody and anti-ICA512 antibody). We also examined the frequency of mtDNA 3243 mutation among Korean Type I (insulin-dependent) diabetic patients with typical and atypical clinical features.

\section{Subjects and methods}

Subjects. During the period from 1 September to 31 October of 1997, we measured fasting plasma C-peptide in 1870 consecutive diabetic patients attending the outpatient diabetes clinic of Asan Medical Center, Seoul, Korea. Among these subjects, 117 patients had the serum C-peptide levels lower than 0.2 $\mathrm{nmol} / \mathrm{l}$ and they were tested for glucagon stimulation. In order to increase the specificity of classification, a lower cut-off value for glucagon-stimulated C-peptide value was adopted $(0.32$ $\mathrm{nmol} / \mathrm{l}$ [17] rather than the usual criteria of $0.6 \mathrm{nmol} / \mathrm{l}[18])$ as a working criterion of Type I (insulin-dependent) diabetes mellitus. By this criterion, 56 patients were considered to have Type I (insulin-dependent) diabetes mellitus with insulin deficiency. We further classified these subjects according to the clinical manifestation. Altogether 26 patients who required insulin treatment within 1 year after diagnosis or who initially had diabetic ketoacidosis (DKA) were classified as typical Type I (insulin-dependent) diabetic patients. Another 30 patients who had non-insulin requiring period at least for 1 year were classified as atypical Type I (insulin-dependent) diabetic patients.

$I C A$. ICA was detected by indirect immunofluorescence on cryostat sections of human pancreas from a blood group $\mathrm{O}$ donor. The results were expressed in Juvenile Diabetes Foundation (JDF) units relative to an international reference standard. A positive result was defined as $8 \mathrm{JDF}$ units or greater. The assay was established with the help of Diabetes Research Center in the University of Washington (Seattle, Wash., USA). The centre participates in the ICA proficiency tests sponsored by the International Diabetes Workshop.

Anti-GAD antibody and anti-ICA512 antibody. Anti-GAD antibody and anti-ICA512 antibody were measured by radioimmunoassay using commercially available kits (RSR, Cardiff, United Kingdom for anti-GAD antibody and Brahms, Berlin, Germany for anti-ICA512 antibody). Results were expressed as unit $/ \mathrm{ml}$ based on the radioactivity of the reference serum. The upper limit for a normal result, as determined using sera from blood donors was $1 \mathrm{unit} / \mathrm{ml}$ and $2 \mathrm{unit} / \mathrm{ml}$ respectively, which exceeded the mean +3 SEM.

Mitochondrial DNA 3243 mutation. Genomic DNA was extracted from peripheral blood lymphocytes. To detect the 3243 bp mutation, the relevant region of mtDNA was amplified by the polymerase chain reaction (PCR) using forward primer (5' AGGACAAGAGAAATAAGGCC 3') and reverse primer (5' TAGAAGAGCGATGGTGAGAG 3'). The reaction condition was: 30 cycles of denaturation at $93{ }^{\circ} \mathrm{C}$ for $1 \mathrm{~min}$, annealing at $55^{\circ} \mathrm{C}$ for $1 \mathrm{~min}$, extension at $72^{\circ} \mathrm{C}$ for $1 \mathrm{~min}$. These fragments were digested with restriction endonuclease ApaI, and subjected to $2 \%$ agarose gel electrophoresis, followed by southern blotting using PCR-amplified 428 bp fragment (3130-3558 bp) as a hybridization probe. When ApaI digestion suggested the presence of the mutation, mtDNA fragments were sequenced with automated DNA sequencer.

C-peptide. Plasma C-peptide levels were measured by radioimmunoassay (Daiichi, Tokyo, Japan). The detection limit of the assay was $0.03 \mathrm{nmol} / \mathrm{l}$.

Statistical analysis. Statistical analysis was done with SPSS (Statistical Package for Social Sciences, SPSS Inc, Chicago, Ill., USA). Comparison of means between groups was done using student's $t$ test. A Chi square test was used for comparing proportions between the groups. Data are presented as median (range) or means \pm SEM. A $p$ value of less than 0.05 (twotailed) was considered to be statistically significant. 
Table 1. Comparison of typical and atypical Type I (insulin-dependent) diabetes

\begin{tabular}{|c|c|c|c|}
\hline & Typical Type I diabetes & Atypical Type I diabetes & $p$-value \\
\hline$n$ & 26 & 30 & \\
\hline Age of onset ${ }^{\mathrm{a}}$ & $27.5(9-55)$ & $40(15-71)$ & $<0.01$ \\
\hline Sex (M:F) & $12: 14$ & $15: 15$ & NS \\
\hline Family history of diabetes & $12 \%(3 / 26)$ & $27 \%(8 / 30)$ & NS \\
\hline History of DKA & $23 \%(6 / 26)$ & $0 \%(0 / 30)$ & $<0.05$ \\
\hline Duration of diabetes (years) ${ }^{\mathrm{a}}$ & $5(1-18)$ & $10(1-25)$ & $<0.01$ \\
\hline
\end{tabular}

a Data given as median (range)

${ }^{\mathrm{b}}$ Data given as mean $\pm \mathrm{SEM}$

Table 2. Prevalence of islet auto-antibodies and mitochondrial DNA mutation

\begin{tabular}{llll}
\hline & Typical Type I diabetes & Atypical Type I diabetes & $p$-value \\
\hline ICA & $50 \%(13 / 26)$ & $23 \%(7 / 30)$ & NS \\
Anti-GAD antibody & $35 \%(9 / 26)$ & $23 \%(7 / 30)$ & NS \\
Anti-ICA512 antibody & $50 \%(13 / 26)$ & $23 \%(7 / 30)$ & NS \\
One or more of the above & $77 \%(20 / 26)$ & $57 \%(17 / 30)$ & NS \\
MtDNA mutation & $0 \%(0 / 26)$ & $10 \%(3 / 30)$ & NS \\
\hline
\end{tabular}

Table 3. Clinical characteristics of the patients showing mitochondrial DNA 3243 mutation

\begin{tabular}{|c|c|c|c|}
\hline & Case 1 & Case 2 & Case 3 \\
\hline Sex/Age & $\mathrm{M} / 36$ & $\mathrm{M} / 31$ & $\mathrm{~F} / 30$ \\
\hline BMI $\left(\mathrm{kg} / \mathrm{m}^{2}\right)$ & 21.6 & 18.9 & 19.1 \\
\hline Fasting C-peptide (nmol/l) & $<0.1$ & 0.15 & 0.14 \\
\hline Age of onset (years) & 22 & 27 & 30 \\
\hline Duration of diabetes (years) & 14 & 4 & 4 \\
\hline Time to insulin use (years) & 2 & 4 & 2 \\
\hline Auto-antibodies against islet cell (ICA, anti-GAD, anti-ICA512) & $(-)$ & $(-)$ & $(+)$ for ICA512 \\
\hline Sensorineural hearing loss & Yes & Yes & No \\
\hline
\end{tabular}

\section{Results}

Clinical characteristics of the patients. The median age of diagnosis was 27.5 years for typical group (range: 9-55 years), while it was 40 years for atypical group (range: $15-71$ years, $p<0.01$ vs typical group). 22 out of 30 patients in the typical group required insulin from diagnosis, and median duration from diagnosis to insulin requirement was 4.5 years for atypical group (Table 1).

Prevalence of islet cell auto-antibodies. Overall, $77 \%$ of typical group and $57 \%$ of atypical group had at least one among the three auto-antibodies. The frequency of individual auto-antibodies tended to be higher in typical group, but statistical significance was not reached (Table 2).

Mitochondrial DNA 3243 point mutation. Mitochondrial DNA 3243 mutation was not found in typical Type I (insulin-dependent) diabetic patients. Howev- er, 3 out of 30 patients $(10 \%)$ who had atypical Type I (insulin-dependent) diabetes were found to have mtDNA 3243 mutation (Table 2). ICA and antiGAD antibody were not found in these patients but anti-ICA512 antibody was positive in one patient. Family history of diabetes on the maternal side was found in 2 cases. In 2 cases, sensorineural hearing loss was found (Table 3 ).

\section{Discussion}

The former WHO classification of IDDM was based on clinical manifestations, such as abrupt onset of symptoms, insulinopenia and dependence on insulin to sustain life and proneness to ketosis. However, this classification was not straightforward, and many investigators have used glucagon-stimulated or postprandial plasma C-peptide values as measurements of insulin secretory capacity [19]. While undetectable plasma C-peptide values support the diagnosis of 
IDDM, many patients thought to have IDDM on clinical grounds retain some insulin secretory capacity. For example, the DCCT research group found that residual beta-cell function $(0.2-0.5 \mathrm{nmol} / \mathrm{l}$ after stimulation by standard test meal) continues for a longer period of time in adults compared to adolescent with IDDM, and that this endogenous insulin secretion makes an important contribution to metabolic control $[20,21]$. In our study, we used glucagonstimulated C-peptide concentrations [22] in order to avoid possible variations inherent in test meals. A previous study indicated that equal discrimination between insulin-requiring and non-insulin-requiring patients was found by measuring postprandial or glucagon-stimulated C-peptide concentrations, and that postprandial C-peptide value of $0.5 \mathrm{nmol} / 1$ was equivalent to glucagon-stimulated C-peptide value of 0.6 $\mathrm{nmol} / \mathrm{l}[19]$.

It has been argued that clinical characteristics of diabetic patients in the Far East Asian populations might be different from those in other populations. In contrast to Caucasians and other populations, the non-obese form of Type II diabetes is more prevalent than obese form in the Far East Asian countries [23, 24]. A substantial number of these patients could belong to SPIDDM or LADA [25]. This study indicates that there is indeed a subgroup of Type I (insulin-dependent) diabetic patients who initially present as NIDDM and progress to insulin deficiency. However, the actual number of these patients appears not to be high in Korea. The present study shows that only $1.6 \%(30 / 1860)$ of diabetic patients attending a general hospital have a history of progressive insulin deficiency. Although we did not measure auto-antibodies in the remainder, we reported previously that $4.9 \%$ $(12 / 245)$ and $4.1 \%(10 / 245)$ of Type II Korean diabetic patients were positive for ICA and anti-GAD antibody, respectively [26], a lower rate than reported in Caucasians [27]. Similarly, it was also reported that only $1.7 \%$ (2 of 121 ) of previously undetected Type II diabetic patients in Korea had anti-GAD antibody [28]. Taken together with the finding that the incidence of Type I (insulin-dependent) diabetes in Japan and Korea is among the lowest in the world [29, 30], these results suggest that autoimmunity might not be a major cause of diabetes in this country.

This study shows that $77 \%$ of typical Type I (insulin-dependent) diabetic patients had at least one out of three islet cell auto-antibodies (i.e., ICA, antiGAD antibody and anti-ICA512 antibody). A comparison with the reports that more than $90 \%$ of Type I (insulin-dependent) diabetics in Western countries had at least one of these islet cell auto-antibodies $[6,7]$ indicates that the prevalence of auto-antibodies in Korean Type I (insulin-dependent) diabetic patients appears to be rather low. The prevalence of ICA decreases as the duration of diabetes increases, and the lower prevalence of auto-antibodies in Korean Type I (insulin-dependent) diabetic patients could in part be attributed to the inclusion of patients with longer diabetic duration. However, it is also quite possible that cause(s) other than autoimmunity play an important role in the pathogenesis of Type I (insulin-dependent) diabetes, especially in the Far East Asian countries. In this regard, a new subset of Type I (insulin-dependent) diabetes mellitus was described [31] among Japanese people characterized by a rapid onset, evidence of exocrine pancreatic insufficiency and absence of islet cell autoimmunity. Because of the limitation of our study design, however, it was not possible to estimate how many of our Type I (insulin-dependent) diabetic patients belonged to this category.

In our study, $57 \%$ of atypical Type I (insulin-dependent) diabetic patients had one or more among three auto-antibodies. A previous study reported that the prevalence of ICA in SPIDDM patients was higher $(43 \%)$ than that in typical IDDM patients $(25 \%)$ [2]. It has been suggested that antigenic stimulation from the remaining beta cell would promote persistent antibody production. However, the prevalence of ICA in our atypical group was not higher than that in the typical group and only $23 \%$ of the patients had ICA. The cause of this discrepancy is not known.

Of interest in our study is that mtDNA 3243 mutation was detected in $10 \%$ of atypical Type I (insulindependent) diabetes. This is in agreement with a previous study [14] that reported $5.5 \%$ prevalence of mtDNA mutation among patients with Type I (insulin-dependent) diabetes and family history of diabetes. Among entire diabetic patients in Western countries and Japan, the prevalence of mtDNA mutation was reported to be about $0.5-2.4 \%$ [12-15]. Thus, our data suggest that mtDNA mutation can be detected in high proportion of patients if the study is done in subjects having progressive insulin deficiency. In our study, one patient with mtDNA mutation had anti-ICA512 antibody. A previous study also reported three patients with mtDNA 3243 mutation among 27 Japanese ICA-positive diabetic patients who were initially non-insulin-dependent [32]. It is not known at present, however, whether mtDNA mutation and autoimmunity are causally related.

In summary, this study showed that autoimmunity is a less frequent cause of Type I (insulin-dependent) diabetes mellitus in Korea. The prevalence of auto-antibodies in Korean typical and atypical Type I (insulindependent) diabetic patients was $77 \%$ and $57 \%$, respectively. $10 \%$ of atypical Type I (insulin-dependent) diabetic patients showed mtDNA 3243 mutation but the remainder had no identifiable cause.

Acknowledgements. This study was supported by a grant (HMP-99-M-08-0004) from the 1999 Good Health Research and Development Project, Ministry of Health and Welfare, Korea. 


\section{References}

1. World Health Organization Study Group on Diabetes Mellitus (1985) Technical Report Series No 727, WHO, Geneva

2. Kobayashi T, Tamemoto K, Nakanishi K et al. (1993) Immunogenetic and clinical characterization of slowly progressive IDDM. Diabetes Care 16: 780-788

3. Lee KU, Kim SW, Park JY, Ko KS, Rhee BD, Min HK (1995) Clinical heterogeneity of insulin dependent diabetes mellitus in Korea. Diabetes Res Clin Pract 27: 159-162

4. Tuomi T, Groop LC, Zimmet PZ, Rowley MJ, Knowles W, Mackay IR (1993) Antibodies to glutamic acid decarboxylase reveal latent autoimmune diabetes mellitus in adults with a non-insulin-dependent onset of disease. Diabetes 42: $359-362$

5. Report of the expert committee on the diagnosis and classification of diabetes mellitus (1997) Diabetes Care 20: 1183-1197

6. Gorus FK, Goubert P, Semakula C et al. (1997) IA-2-autoantibodies complement $\mathrm{GAD}_{65}$-auto-antibodies in new-onset IDDM patients and help predict impending diabetes in their siblings. Diabetologia 40: 95-99

7. Savola K, Bonifacio E, Sabbah E et al. (1998) IA-2 antibodies - a sensitive marker of IDDM with clinical onset in childhood and adolescence. Diabetologia 41: 424-429

8. Lemkes HHPJ, de Vijlder M, Struyvenberg P, van der Kamp JJP, Frolich M (1989) Maternal inherited diabetesdeafness of the young (MIDDY); A new mitochondrial syndrome. Diabetologia 32: 509A (Abstract)

9. van den Ouweland JMW, Lemkes HHPJ, Ruitenbeek W et al. (1992) Mutation in mitochondrial tRNA ${ }^{\text {Leu(UUR) }}$ gene in a large pedigree with maternally transmitted type II diabetes mellitus and deafness. Nat Genet 1: 368-371

10. Reardon W, Ross RJM, Sweeney MG et al. (1992) Diabetes mellitus associated with a pathogenic point mutation in mitochondrial DNA. Lancet 340: 1376-1379

11. Kadowaki H, Tobe K, Mori Y et al. (1993) Mitochondrial gene mutation and insulin-deficient type of diabetes mellitus. Lancet 341: 893-894

12. Hart LM, Lemkes HHPJ, Heine RJ et al. (1994) Prevalence of maternally inherited diabetes and deafness in diabetic populations in the Netherlands. Diabetologia 37: 1169-70

13. Katagiri H, Asano T, Ishihara H et al. (1994) Mitochondrial diabetes mellitus: Prevalence and clinical characterization of diabetes due to mitochondrial tRNA ${ }^{\text {Leu(UUR) }}$ gene mutation in Japanese patients. Diabetologia 37: 504-510

14. Kadowaki T, Kadowaki H, Mori Y et al. (1994) A subtype of diabetes mellitus associated with a mutation of mitochondrial DNA. N Engl J Med 330: 962-968

15. Otabe S, Sakura H, Shimokawa K et al. (1994) The high prevalence of the diabetic patients with a mutation in the mitochondrial gene in Japan. J Clin Endocrinol Metab 79: 768-771

16. Maassen JA, van den Ouweland JMW, Hart LM, Lemkes HHPJ (1997) Maternally inherited diabetes and deafness: A diabetic subtype associated with a mutation in mitochondrial DNA. Horm Metab Res 29: 50-55

17. Gjessing HJ, Matzen LE, Faber OK, Frøland A (1989) Fasting plasma C-peptide, glucagons stimulated plasma C- peptide, and urinary C-peptide in relation to clinical type of diabetes. Diabetologia 32: 305-311

18. Hother-Nielsen O, Faber O, Sørensen NS, Beck-Neilsen H (1988) Classification of newly diagnosed diabetic patients as insulin-requiring or non-insulin-requiring based on clinical and biochemical variables. Diabetes Care 11: 531-537

19. Koskinen PJ, Viikari JSA, Irjala KMA (1988) Glucagonstimulated and postprandial plasma C-peptide values as measures of insulin secretory capacity. Diabetes Care 11: 318-322

20. The DCCT Resarch Group(1987) Effects of age, duration and treatment of insulin-dependent diabetes mellitus on residual beta-cell function: observation during eligibility testing for the diabetes control and complications trial. J Clin Endocrinol Metab 65: 30-36

21. The Diabetes Control and Complications Trial Research group (1998) Effect of intensive insulin therapy on residual beta-cell function in patients with type 1 diabetes in the Diabetes Control and Complications Trial. Ann Intern Med 128: 517-523

22. Faber OK, Binder C (1977) C-peptide response to glucagon: a test for the residual beta-cell function in diabetes mellitus. Diabetes 26: 605-610

23. Diabetes Drafting Group (1985) Prevalence of small vessel and large vessel disease in diabetic patients from 14 centres: The World Health Organisation multinational study of vascular disease in diabetics. Diabetologia 28: 615-640

24. Park JY, Lee KU, Kim CH et al. (1997) Past and current obesity in Koreans with non-insulin-dependent diabetes mellitus. Diabetes Res Clin Pract 35: 49-56

25. Bennett PH, Bogardus C, Tuomilehto J, Zimmet P (1992) Epidemiology and natural history of NIDDM: non-obese and obese. In: Alberti KGMM, DeFronzo RA, Keen H, Zimmet P (eds) International Textbook of Diabetes Mellitus. John Wiley \& Sons, New York, pp 147-176

26. Ko KS, Hong SK, Lee KU et al. (1998) The frequency of ICA and anti-GAD antibody in Korean IDDM and NIDDM patients. J Korean Diabetes Assoc 22: 312-319

27. Groop LC, Bottazzo GF, Donich D (1986) Islet cell antibodies identify latent type 1 diabetes in patients 35-75 years at diagnosis. Diabetes 35: 237-241

28. Park YS, Lee HK, Zimmet P et al. (1996) The low prevalence of immunogenetic markers in Korean adult-onset NIDDM patients. Diabetes Care 19: 241-245

29. LaPorte RE, Tajima N, Åkerblom HK et al. (1985) Geographic differences in the risk of insulin-dependent diabetes mellitus: The importance of registries. Diabetes Care 8: 101-107

30. Ko KW, Yang SW, Cho NH (1994) The incidence of IDDM in Seoul from 1985 to 1988. Diabetes Care 17: 1473-1475

31. Imagawa A, Hanafusa T, Miyagawa J, Matsuzawa Y, Osaka IDDM Study Group (2000) A novel subtype of type 1 diabetes mellitus characterized by a rapid onset and an absence of diabetes-related antibodies. N Engl J Med 342: 301-307

32. Oka Y, Katagiri H, Yazaki Y, Murase T, Kobayashi T (1993) Mitochondrial gene mutation in islet-cell-antibodypositive patients who were initially non-insulin-dependent diabetics. Lancet 342: 527-528 